\title{
The media accountability of independent regulatory agencies
}

\author{
Maggetti, Martino
}

\begin{abstract}
Independent regulatory agencies (IRAs) are increasingly attracting academic and societal attention, as they represent the institutional cornerstone of the regulatory state and play a key role in policy-making. Besides the expected benefits in terms of credibility and efficiency, these regulators are said to bring about a 'democratic deficit', following their statutory separation from democratic institutions. Consequently, a 'multi-pronged system of control' is required. This article focuses on a specific component of this system, that is, the media. The goal is to determine whether media coverage of IRAs meets the necessary prerequisites to be considered a potential 'accountability forum' for regulators. The results of a comparison of two contrasted cases - the British and Swiss competition commissions - mostly support the expectations, because they show that media coverage of IRAs corresponds to that of the most relevant policy issues and follows the regulatory cycle. Furthermore, a systematic bias in media coverage can be excluded.
\end{abstract}

DOI: https://doi.org/10.1017/S1755773911000208

Posted at the Zurich Open Repository and Archive, University of Zurich

ZORA URL: https://doi.org/10.5167/uzh-66107

Journal Article

Published Version

Originally published at:

Maggetti, Martino (2012). The media accountability of independent regulatory agencies. European Political Science Review, 4(3):385-408.

DOI: https://doi.org/10.1017/S1755773911000208 


\section{European Political Science Review}

http://journals.cambridge.org/EPR

Additional services for European Political Science Review:

Email alerts: $\underline{\text { Click here }}$

Subscriptions: Click here

Commercial reprints: Click here

Terms of use : $\underline{\text { Click here }}$

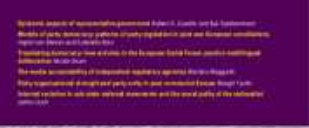

\section{The media accountability of independent regulatory agencies}

Martino Maggetti

European Political Science Review / Volume 4 / Issue 03 / November 2012, pp 385 - 408

DOI: $10.1017 /$ S1755773911000208, Published online:

Link to this article: http://journals.cambridge.org/abstract_S1755773911000208

How to cite this article:

Martino Maggetti (2012). The media accountability of independent regulatory agencies. European Political Science Review, 4, pp 385-408 doi:10.1017/S1755773911000208

Request Permissions : $\underline{\text { Click here }}$ 


\title{
The media accountability of independent regulatory agencies
}

\author{
MARTINO MAGGETTI* \\ Lecturer, Department of Political Science, Affolternstrasse 56, University of Zurich, Zurich, Switzerland
}

\begin{abstract}
Independent regulatory agencies (IRAs) are increasingly attracting academic and societal attention, as they represent the institutional cornerstone of the regulatory state and play a key role in policy-making. Besides the expected benefits in terms of credibility and efficiency, these regulators are said to bring about a 'democratic deficit', following their statutory separation from democratic institutions. Consequently, a 'multi-pronged system of control' is required. This article focuses on a specific component of this system, that is, the media. The goal is to determine whether media coverage of IRAs meets the necessary prerequisites to be considered a potential 'accountability forum' for regulators. The results of a comparison of two contrasted cases - the British and Swiss competition commissions - mostly support the expectations, because they show that media coverage of IRAs corresponds to that of the most relevant policy issues and follows the regulatory cycle. Furthermore, a systematic bias in media coverage can be excluded.
\end{abstract}

Keywords: accountability; independence; IRAs; media; regulation

\section{Introduction}

The institutionalization of the regulatory state in Europe entailed new modes of governance and new technologies of regulation after liberalization, privatization, and re-regulation (Majone, 1996b; Coen and Heritier, 2005; Levi-Faur, 2005; Gilardi, 2008; Héritier and Eckert, 2008). Particularly since the 1990s, following the regulatory approach promoted by the European Union (EU) and the global trend of agencification, numerous independent regulatory agencies (IRAs) were established in member countries and at the EU level to regulate economic and social issues, such as banking and finance, telecommunications, civil aviation, railway services, food safety, the pharmaceutical industry, electricity, environmental protection, and personal data privacy (Thatcher, 2002c,d; Pollitt et al., 2004; Yesilkagit, 2004; Christensen and Yesilkagit, 2006; Christensen and Laegreid, 2006a, b, 2007; Gilardi, 2008; Laegreid et al., 2008). These agencies consist of structurally disaggregated public sector organizations with their own budgets, defined as legal entities by public law, directed by management boards headed by

\footnotetext{
* E-mail: maggetti@ipz.uzh.ch
} 
appointed chairpersons, and disposing of secretariats in charge of day-to-day regulatory tasks (Verschuere et al., 2006). They enjoy considerable public authority and they cumulate key regulatory and policy-making competencies such as rule-making, monitoring, sanctioning, and adjudication (Maggetti, 2009b), so that they epitomize a mode of governance in line with the observation that 'the real work of running democracies is now carried out by the unelected' (Vibert, 2007). In fact, they are 'neither directly elected by the people, nor directly managed by elected officials' (Thatcher and Stone Sweet, 2002). This apparent imbalance between power and responsibility led to the identification of a 'democratic deficit' in the European regulatory state (Majone, 1999, 2002; Roberts, 2001; Follesdal and Hix, 2006). Whereas the diagnosis of the intensity of this deficit may vary, it has been observed that governments can delegate regulatory authority to independent regulators, but not their democratic legitimacy, leading to a 'net loss' of democratic legitimacy for the political system (Majone, 1999, 2001a, 2005; Maggetti, 2009a, 2010).

In response to these considerations, it was argued that 'majoritarian standards' of legitimacy are not appropriate for independent regulators (Majone, 2002). Their legitimacy should instead be appreciated with reference to alternative standards, especially through the revivification of the concept of 'accountability'. Majone points repeatedly to the need for a 'multi-pronged system of controls' to keep regulatory bodies accountable (Majone, 1996a, 2002). This system consists of a variety of control mechanisms, such as (1) specification of clear and narrow objectives; (2) oversight by governmental and parliamentary committees; (3) procedural requirements like hearings and reporting duties; (4) judicial review; (5) professionalism and peer review; and (6) transparency and public participation. Academic research has focused so far on the first four points, which refer to traditional accountability arrangements between bureaucracy and other branches of the state (Schedler, 1999; Mulgan, 2000, 2003; Lodge, 2004; Verschuere et al., 2006; Busuioc, 2009), and, to a lesser extent, to the fifth mechanism, which is distinctive of independent bodies (Maggetti and Gilardi, 2010). Conversely, the last solution has been either neglected or dismissed as scarcely relevant, because direct public participation in regulatory governance is considered empirically negligible and even normatively undesirable (Sosay, 2006). In particular, it is believed that the participation of an increased heterogeneous number of actors would undermine the decision-making capacity of IRAs, that is, their raison d'être (Majone, 1999).

The goal of this paper is to examine another, indirect, possible venue for securing transparency and responsiveness with regard to independent regulators, that is, their media coverage (Arnold, 2004; Voltmer, 2010). In this context, a specific question is explored: can the media help to hold independent regulators accountable, in line with the observation that 'in many countries, the media are fast gaining power as informal forums for political accountability' (Bovens, 2007)? The next two sections discuss the relevance of media scrutiny for the accountability of regulators and, respectively, present some exploratory expectations about the frequency and tone of media coverage. Then, these expectations 
are operationalized for two contrasted cases: the British and Swiss competition commissions. The empirical analysis and conclusions follow. The main findings indicate that the media coverage of agencies corresponds to that of the most relevant policy issues and follows approximately the regulatory cycle. Furthermore, a systematic negative or positive bias in media coverage can be excluded.

\section{Accountability and the media}

Thomas Jefferson, in the spirit of the first amendment to the United States' Constitution, famously stated that 'the functionaries of every government have propensities to command at will the liberty and property of their constituents. There is no safe deposit for these but with the people themselves, nor can they be safe with them without information. Where the press is free, and every man able to read, all is safe' (Thomas Jefferson to Charles Yancey, 1816. ME 14:384). In this vein, recent studies have shown that mass media are 'by far the most important' source of information about officials' performance (Arnold, 2004), representing a 'necessary condition' for the existence of democratic government (Dahl, 1989) and a precondition for accountability (Coglianese and Howard, 1998; Lee, 1999; Besley and Burgess, 2001; Besley et al., 2002; Voltmer, 2010). The media can play a key role in enabling citizens - who have imperfect information about government activities - to monitor the actions of ministers and civil servants, leading to a government that is more accountable and responsive to its citizens (Besley and Burgess, 2001; Besley et al., 2002; Besley and Prat, 2006) and rendering elected politicians more accountable (Roberts, 2002; Strömberg, 2004; Louw, 2005; Snyder and Strömberg, 2008). ${ }^{1}$ In particular, active and persistent media coverage encourages the formation of an informed public opinion (O'Donnell, 1998), whereas press criticism and support are considered crucial for obtaining justifications from governments and civil service (Meyer, 2004). The media could theoretically provide an 'accountability forum' (Bovens, 2007) that is particularly suitable for IRAs, constituting 'one element of a complex accountability system' (Hodge and Coghill, 2007), which would not hinder their independence (Majone, 1996a, 2002).

Accountability means that an actor who is in a position of responsibility in relationship with the interests of another actor is required to give an account of the conduct of his duties, whereas the second actor can either reward or sanction the former (Schedler, 1999; Castiglione, 2006). Bovens underlines the fact that accountability should be conceptualized as a social relationship between an actor and its 'accountability forum', which can be an individual or a collective actor through whom the first actor is held accountable (Bovens, 2007). Following Bovens, in many countries, the media are fast gaining power as informal forums

\footnotetext{
${ }^{1}$ Ideally, free media are expected to act as the societal institution that 'contributes to public accountability without being under the control of any other actor' (Fox, 2000), that is, following an endogenous logic stemming from market incentives and journalistic goals (Besley and Prat, 2006).
} 
for political accountability (Bovens, 2007). The media might constitute a particularly relevant accountability forum for IRAs for two reasons. First, public communication is a requisite for the accountability of political institutions (Sarcinelli, 1987; Dahl, 1989), which is particularly important when policy-making takes place behind closed doors and scarce democratic responsiveness exists (Voltmer and Eilders, 2003). In fact, the media do guide opinion formation and perception (de Vreese et al., 2006), especially when they cover issues that are overly technical or with which individuals are less familiar (Zaller, 1992; Vogel, 1996; Bryant and Zillmann, 2002). This is the case of independent regulators, whereby citizens derive most of what they know about the issues dealt with from the media, and in turn, the media might help to 'extend' the accountability of these bodies (Scott, 2000).

Second, the media represent a venue for policy-makers for the appraisal of regulatory outcomes, performing a 'fire-alarm' function (McCubbins et al., 1987). Because the political principals suffer from a structural informational disadvantage vis-à-vis independent regulatory agencies, they must rely on external sources of information to monitor whether the agency is acting according to the predefined notion of the 'public interest' before eventually deciding to engage in costly political-oversight activities (Hopenhayn and Lohmann, 1996). As such, media coverage constitutes an important 'linkage mechanism' between regulatory agencies and policy-makers (Waterman et al., 1998; Waterman and Rouse, 1999; Carpenter, 2002), by playing a key role in communicating policy ideas and framing issues (Coglianese and Howard, 1998). At the same time, the media affect the setting of the political agenda (Walgrave et al., 2008), given that decisionmakers, for instrumental reasons, look for regulatory policies that reflect so-called public opinion (Stimson et al., 1994).

Therefore, the accountability of IRAs before the media can be examined by operationalizing the two components of the definition outlined above: on the one hand, (1) the extent to which the media give an account of IRAs' conduct can be measured with the amount of media coverage with reference to the official goals of delegation, that is, the expected credibility of regulators associated with their supposed independence, and the aspiration of enhancing decision-making efficiency thanks to their technical expertise (Majone, 1994b, 1996b, 1997a, b; Gilardi, 2002; Moran, 2002; Thatcher, 2002a, b, c; Elgie and McMenamin, 2005; Levi-Faur, 2005). Policy credibility is the expectation that an announced policy will be properly carried out (Drazen and Masson, 1994) to create credible policy commitments vis-à-vis stakeholders (e.g. investors), consumers, and citizens (Shepsle, 1991). It is considered a crucial condition for solving the time-inconsistency problem related to the political cycle (Kydland and Prescott, 1977; Barro and Gordon, 1983). Decision-making efficiency refers to the resource-saving implementation of predetermined goals (Blühdorn, 2006). That is, it involves reducing decisionmaking costs by taking advantage of agencies' expertise, while avoiding the enactment of policies that are different from those preferred by the political 
decision-makers (Epstein and O'Halloran, 1999; Bendor et al., 2001; Majone, 2001c). ${ }^{2}$ On the other hand, (2) the positive or the negative tone of media coverage relating to agencies' credibility and efficiency can be considered an important symbolic sanction or reward, both of which have crucial consequences on their activeness, effectiveness, and prospects for survival. ${ }^{3}$ In fact, 'not only performance but also the perceived appearance of performance [...] challenges the organisation's legitimacy and potential survival' (Lodge, 2002).

\section{Expectations about the media accountability of agencies}

It has been noted that political communication is increasingly 'mediated': political actors depend on the mass media to reach and mobilize citizens (Manin, 1996), and citizens ever more frequently form their political opinions based on what they learn from the news media (Swanson and Mancini, 1996; Gerber, 1999; Hallin and Mancini, 2004). Furthermore, it has been observed that the media can act as a partially autonomous actor that shapes political institutions and informs the public with growing independence from governments, parties, and interest groups

2 The explanatory power of these normative arguments is limited, as there is cumulative evidence supporting the relevance of non-functional factors for the establishment of independent regulators, drawing from organizational theory and sociological institutionalism (Gilardi, 2005; Christensen and Yesilkagit, 2006). In particular, emulative processes and strategies for coping with political uncertainty and blame shifting are frequently highlighted (Thatcher and Stone Sweet, 2002; Gilardi, 2005, 2008; Christensen and Yesilkagit, 2006). However, the official goals of delegation in terms of credibility and efficiency represent a relevant analytical benchmark when, instead of examining why agencies are created, the focus is on the consequences of delegating public authority to IRAs, as in the present research study. These official goals are further relevant because, from a new institutional perspective, although created following the dynamics of symbolic diffusion, once in place, agencies are expected to 'take on a life of their own' (Pollack, 1996) and also exert a direct impact on regulatory practices (Christensen and Lægreid, 2003).

3 The tone of the media's coverage is particularly important from a reputational perspective. On the one hand, the media represent a point of view that is socially relevant for building a reputation of credibility; that is, a point of view that is relevant when regulatees, stakeholders, and the public at large believe in the proper implementation of the announced policies and make choices based on these expectations (Brabazon, 2000). By analogy, in the business management literature, it is widely accepted that media-provided information affects the credibility of firms and, consequently, investors' behaviour, influencing performances such as price rate and stock turnover (Pollock and Rindova, 2003). In fact, the media constitute a crucial element of the process of contagion that proceeds from the level of individual cognition to the level of social propagation and back to that of individual cognition, transmitting the image of the corporation through an informal network and eventually affecting its credibility (Balboni, 2008). On the other hand, the tone of the media's evaluation of efficiency is crucial for IRAs. The media provide a forum for debate and dissemination of information, recording evaluations, reducing information asymmetry, and influencing the opinions of stakeholders by reputational mechanisms (Deephouse, 2000), while organizational reputation is an essential property of regulators that widely influences the effectiveness of their actions (i.e., the factual delivery of their intended outcomes) (Blühdorn, 2006). Specifically, a reputation for efficiency allows agencies to build networks and coalitions, exert political influence, increase their room for manoeuvre vis-à-vis elected politicians, and reinforce their position before those being regulated (Carpenter, 2001a, b). In addition, it is instrumental in gaining support from interest groups concerned with regulatory reforms (Krause and Douglas, 2005). 
(Mazzoleni and Schulz, 1999; Kepplinger, 2002; Strömbäck and Esser, 2009). However, one should recognize that the media are not necessarily impartial when evaluating agencies' functioning. On the one hand, politicians and representatives of organized groups can try to use the media strategically to convey their points of view. On the other hand, they also follow their commercial and/or ideological goals. Therefore, the media are neither neutral evaluators reflecting reality nor mere channels of communication for political actors (Strömbäck and Esser, 2009). They are indeed involved in the process of constructing reality and impose their views on the story (Swanson, 1981; Mazzoleni, 1987; Altheide and Snow, 1988). In addition, media are selective, that is, they do not cover everything that political actors do, but do focus on those issues that have 'the most direct impact on the public' (Coglianese and Howard, 1998) and on 'important and interesting news' (Cook, 1998). Whether the media can, however, provide the minimal conditions to render IRAs accountable - notwithstanding the above-mentioned shortcomings and variations in institutional settings, political-administrative factors, varieties of media systems, and agencies' characteristics - constitutes the main empirical question of this article, similar to previous research on the media coverage of the US congress (Arnold, 2004). ${ }^{4}$

As anticipated in the previous section, the first component of media accountability corresponds to evidence of regular media scrutiny of IRAs with reference to their official goals, credibility, and efficiency, consistent with the ideal account of media as watchdogs of the political process (Besley et al., 2002; Curran, 2005). However, establishing an absolute benchmark for the level of media coverage would be arbitrary. Instead, it can be appraised with the following three indications, which are in line with previous research on media accountability (Arnold, 2004; Voltmer, 2010): (1) the average frequency of news regarding IRAs' credibility and efficiency should be roughly comparable to that of other politically relevant issues; (2) given the growing role of independent regulators, the frequency of media coverage, at an aggregated level, should follow a positive trend; and (3) media attention is expected to follow the regulatory cycle: news is expected to peak around events that are relevant for the investigated IRAs, such as the opening of a new important inquiry or the publication of the annual report.

The other component of accountability is even trickier to detect. The solution adopted in this article is to consider that media do apply symbolic sanctions and rewards when they consistently use a negative or a positive tone in news stories that have an evaluative focus regarding the credibility and efficiency of IRAs. Three minimal expectations regarding the tone of media evaluation can be mentioned: (4) the evaluation of agencies' credibility should vary across cases and not be systematically conditioned by a positive bias, which could stem from the

\footnotetext{
${ }^{4}$ Nonetheless, the actual influence of the media on public opinion, politicians, and regulators is beyond the scope of this piece of research, which is limited to the exploration of the subsistence of minimal prerequisites for considering the media as a potential accountability forum for IRAs.
} 
widespread perception of the independent regulator as a 'taken for granted' organizational model and 'socially valued' solution for creating credible commitments (Gilardi, 2005); (5) whereas it has been observed that political news that explicitly evaluates performance is typically negative in tone (Kepplinger and Weißbecker, 1991; Lee, 1999; Clark, 2005), the consistent evaluation of agencies' efficiency requires the media to avoid an unconditional negative bias; and (6) because the media are simultaneously the most important channel of communication for agencies and its most attentive observer (Coglianese and Howard, 1998; Lee, 1999; Besley and Burgess, 2001; Besley et al., 2002; Voltmer, 2010), the media coverage is expected to frame IRAs' credibility and efficiency as typical issues of general interest and thus focus on the topics that are considered relevant for the public.

\section{Methodology}

\section{Case selection and the logic of the comparison}

Following the idea that 'one strategy for explanation [...] would be to select administrative systems that differ most and, from the research into those systems, develop propositions that appear to hold true regardless of the vast differences that may exist among the research locales' (Peters, 2004), this examination of media coverage aims to explore two cases for which IRAs share a medium-high level of factual independence from politicians (Maggetti, 2007) - given that effective delegation is a necessary precondition for the analysis - but that ideally diverge in the other macro- and meso-conditions that might influence the media evaluation of agencies. The aforementioned expectations can be validated or dismissed by comparing two cases that are situated at the two extremes of a continuum of the expected media evaluation of credibility and efficiency: a 'most likely' and a 'least likely' case (Gerring, 2007a, b). In this way, it is possible to examine whether the media can function as an accountability forum despite variations in politicaladministrative factors, institutional settings, media systems, and agencies' characteristics. The application of this research design also allows the drawing of conclusions based on a counterfactual case-oriented logic. For instance, if a theory is disconfirmed even for the 'most likely' case, this can be considered a strong argument against that theory. Similarly, when a theory is confirmed even for the 'least likely' case, it means that this theory deserves further attention and consideration (Gerring, 2004, 2007b; Seawright and Gerring, 2008).

According to this logic, two IRAs are selected: the British competition commission (CC) and the Swiss competition commission (ComCo), both established at the beginning of the years 2000 with the official purpose of promoting 'nonmajoritarian' regulatory governance (Wilks and Bartle, 2002; Maggetti et al., 2011). Competition policy is a politically salient regulatory issue for electorally sensitive politicians (Elgie and McMenamin, 2005), when the functionalist logic of delegation is strong (Christensen and Yesilkagit, 2006), for which media coverage of 
credibility and efficiency should be particularly accurate. In addition, media coverage is examined for a commensurable period of time that is sufficiently long to avoid any potential bias because of contingent phenomena: the years 2006 and 2007. ${ }^{5}$ It is worth stressing that the decisive argument for selecting this timeframe is reminiscent of the regulatory issues under investigation in the two countries. A similar, huge issue was examined in both cases: high concentration in the grocery market, which also represents a topic that is fairly ideologically neutral on the left-right divide. ${ }^{6}$ Two particular features of this study shall be mentioned. First, this contribution does not deal with the reception, political impact, or organizational reactions to media evaluation. Second, the IRAs examined in this article are among the most media-savvy regulators in Western Europe, whereas the contribution of media coverage to their accountability is plausibly inferior for IRAs that work far from the media spotlight. Therefore, the scope of the analysis is purposely limited to the media coverage of powerful, independent, mediatized regulators in Western Europe, which are the most important IRAs and those for which this type of accountability could be particularly relevant. The rest of this section shows how the British CC and the Swiss ComCo represent, respectively, a 'most likely' and a 'least likely' case in terms of the outcomes of media evaluation in the population of West European IRAs.

To begin, these two IRAs are embedded in political-administrative systems that are exceedingly dissimilar. Despite some recent trends towards the devolution of political competencies, the British political system is considered the ideal type of a majoritarian polity (Dunleavy and Margetts, 2001). The electoral system provides each major political party the opportunity to contend for governmental positions, with no need for grand coalitions. Once a candidate is in office, there are few political and institutional checks and balances. Therefore, the government relies on its majority to pass its legislative programmes and to make and implement decisions (Norris, 2001; Armingeon, 2002). The Anglo-Saxon style of public administration traditionally emphasizes management rather than legalism in the performance of public tasks, a contractualist and market-oriented logic, and a careerbased professionalized civil-service system (Peters, 2004). The new public management (NPM) reforms implied both the reinforcement of market-oriented structures and the creation of quangos, semi-public organizations, and semi-autonomous agencies responsible for operational management (Hood et al., 2001). At the same

\footnotetext{
${ }^{5}$ This choice seems reasonable as Arnold's landmark study of the media accountability of the US congress also comprises 2 years (Arnold, 2004).

${ }^{6}$ Specifically, the selected media reported the following issues (as percentages): in the United Kingdom, grocery markets $(39 \%)$, aviation regulation $(17 \%)$, TV media plurality $(16 \%)$, home credit markets $(8 \%)$, book chains $(6 \%)$, payment protection insurance $(3 \%)$, price controls on business banks $(2 \%)$, store cards $(2 \%)$, the telephone directories market $(2 \%)$, and others $(5 \%)$; in Switzerland, grocery markets $(41 \%)$, book markets $(9 \%)$, import/export $(9 \%)$, liberalization of the electricity sector $(6 \%)$, vertical cartels $(6 \%)$, credit cards $(3 \%)$, liberalization of the postal service $(3 \%)$, telecommunications $(3 \%)$, the Zurich airport $(3 \%)$, and others $(17 \%)$. No particular crisis event occurred during this time period.
} 
time, a tendency emerged towards the centralization of control and the use of performance assessment and oversight procedures (Knill, 1998; Moran, 2003).

Conversely, the Swiss political system typically follows a consensual model, traditionally selecting a multi-party concordance government. The decisionmaking process is open, inclusive, and strongly shaped by the pre-parliamentary phase, in which expert committees play a crucial role and political parties, interest groups, and cantons are extensively consulted by the federal administration (Papadopoulos, 2008). The participation of organized interests in policy formulation and collective negotiations is institutionalized, according to neo-corporatist logic (Armingeon, 2002; Katzenstein, 2003). According to the federal structure and the related principle of subsidiarity, political competencies are entrusted to the lowest possible level, especially regarding implementation (Braun, 2003). In addition to this vertical dimension, the fragmentation of the system is increased horizontally by frequent reliance on non-professional administrators, extra-parliamentary commissions, and quasi-state organizations (Varone, 2007). NPM was introduced to impose a greater degree of responsibility and to evaluate the results of public actions. However, it produced contradictory injunctions for civil servants, resulting in an increased 'institutional selfishness and one-purpose specialization' that produced even greater fragmentation, less cooperation, and poorer coordination (Emery and Giauque, 2004; Widmer and Neuenschwander, 2004).

Besides these structural differences, it is important to deal with the meso-level variables that might have a direct impact on the media evaluation of agencies to operationalize the comparison of a 'most likely' and a 'least likely' case. The conditions that follow will systematically predict a better media evaluation of the British CC, in terms of credibility and/or efficiency, compared with the Swiss ComCo. First, the British CC could enjoy more positive coverage, as it is formally more independent than the Swiss ComCo (Gilardi, 2008). Second, the United Kingdom is a member of the EU, which is said to have a positive impact on agencies' activism through the promotion of a strong regulatory approach to sustain the economic integration and the common market (Majone, 1996b). On the contrary, because it operates in a nonmember state, the Swiss ComCo receives at best only indirect support from the EU. Third, the use of ex-post mechanisms to monitor and evaluate the quality of regulatory outcomes, such as oversight control tools and the application of procedures of regulatory impact assessment, might improve the agencies' media evaluation for regulatory efficiency. These instruments are consistently adopted in the United Kingdom, whereas they remain comparatively underdeveloped for Swiss IRAs (Widmer and Neuenschwander, 2004; Radaelli and De Francesco, 2007).

Fourth, the British CC is considered one of the world's leading antitrust authorities (GCR, 2006; Wilks, 2007). Furthermore, its analytical skills and capacities are highly rated by peer agencies, experts, and stakeholders, according to the survey enquiries of the Global Competition Review (five out of five stars). This might enhance its media evaluation for both credibility and efficiency. Conversely, the Swiss ComCo is relatively poorly rated (three out of five stars). Moreover, international experts frequently 
criticize it for its supposed lack of effectiveness (OECD, 2005). Fifth, the type of political economy may also have an impact on the institutional appropriateness of the action of regulators (Hall and Soskice, 2001). Again, the media evaluation for credibility and efficiency should be higher for the British regulator, given that the CC operates within a liberal market economy. Instead, the Swiss ComCo has the task of regulating a coordinated market economy, for which the internal market is traditionally strongly cartelized. This situation could lead to interest groups and private actors that hassle the new wave of regulation-for-competition to challenge the regulatory activity of the competition commission by undermining its reputation.

Sixth, the structure of the media field might influence media perceptions of credibility and efficiency. Media industry concentration appears to be higher in Switzerland, producing incentives for the national media to be more critical towards ComCo, because the press industry might feel threatened by the regulator (Doyle, 2002). On the contrary, in the United Kingdom, the press market is larger and more pluralist, segmented, and quite dynamic. Because there are fewer pressures for regulatory interventions, one can exclude any enduring bias against the CC for this reason. Finally, unlike ComCo, the CC has a strong and active department of press communication and public relations, plausibly doing its best to enhance agencies' media evaluations of credibility and efficiency. In general, the human and financial resources of the British CC are significantly higher than those of the Swiss ComCo (Maggetti, 2007). All these factors increase the chances that the former agency will perform better than the latter in terms of media evaluation of credibility and efficiency.

\section{The assessment of media evaluation}

The empirical analysis focuses on the so-called quality press. Quality newspapers are indeed considered crucial because they influence other media, thus directly or indirectly impacting the public (Coglianese and Howard, 1998). It is widely recognized that the elite press reaches a much larger segment of the public by determining issues and perspectives for the news coverage of all types of media (Kepplinger et al., 2004). ${ }^{7}$ Editorials and commentaries are particularly important in shaping the symbolic environment, although they are unfortunately quite neglected in media coverage studies (Voltmer and Eilders, 2003). In fact, they become increasingly more essential as they respond to the people's need for orientation (Voltmer, 1998), especially concerning 'non-obtrusive' issues such as the action of regulatory agencies that cannot be experienced in everyday life (Lang and Lang, 1984). Moreover, editorials are the articles in which the media's own positions are most openly and legitimately expressed (Eilders, 2000; Eilders, 2002). Therefore, a focus on editorials, commentaries, and interviews would allow for the examination of press articles that include an explicit evaluation of

\footnotetext{
${ }^{7}$ In addition, the perceived quality of information determines the magnitude of its effect on the prior beliefs of readers (Gentzkow and Shapiro, 2006).
} 
the agency in a transparent and direct manner. To investigate how the media evaluate independent regulatory agencies and their regulatory action, a measure of 'media favourableness' will be created. For each newspaper, each article that mentions the investigated agency corresponded to an observation and it was preliminarily coded as an editorial (' $\mathrm{e}$ '), comment ('c'), or interview ('i'). In addition, the day of the publication was recorded. News items in which the agency was marginally cited and ordinary articles in which the journalist referred to the agency without any judgement or comment were excluded from the sample. Then, each article was considered according to the explicit evaluation of two distinct elements that represent the 'official goals' of delegation: the credibility and the efficiency of the related agency (Majone, 1996a, 2000; Franchino, 2002; Gilardi, 2002; Braun and Gilardi, 2006).

Each element was evaluated using four criteria: (1) autonomy from politicians, (2) predictability of decisions, (3) status of board members, and (4) autonomy from regulatees, with regard to credibility; and (1) public-good orientation, (2) uniqueness of the solution, (3) organizational capability, and (4) cost-benefit gains, with regard to efficiency. These criteria referred to a number of empirical measurements of organizational reputation that were derived and adapted from the literature dealing with organizational credibility and efficiency (Peters et al., 1997; Brunetti et al., 1998; Blinder, 1999; Deephouse, 2000; Maeda and Miyahara, 2003; Blühdorn, 2006; de Jonge et al., 2007; Kim et al., 2007; Radaelli and De Francesco, 2007). Accordingly, each criterion can be considered as 'constitutive' of the related element (Goertz, 2006).

Further, the code for each single criterion was assigned a place on a three-point scale by considering whether the article explicitly referred to that criterion in a positive, a negative, or a neutral tone (i.e. no evaluation present; not all editorials were clearly evaluative; some were characterized by a neutral and diagnostic tone). A positive reference to one criterion was coded a ' 1 '; a negative evaluation was coded a ' -1 '; and a neutral evaluation was coded a ' 0 '. In turn, each element was nominally evaluated as positive, negative, or neutral according to the positive, negative, or neutral value of the sum of the four criteria defining that element. Following this approach, an article that positively evaluates IRAs' autonomy from politicians constitutes an instance of positive evaluation of credibility. More than one indicator can be simultaneously present in a news article. The coding procedure is consistent across newspapers. This information can be summarized by calculating ' $c$ ', the coefficient of media favourableness (Deephouse, 2000). According to Deephouse, ' $c$ ' measures the relative proportion of favourable to unfavourable articles while controlling for the overall volume of articles. Consistent with prior research, each article is given equal weight in the measure. The formula for calculating ' $c$ ' is

$$
c=\left\{\begin{array}{l}
\left(f^{2}-f u\right) /(\text { total })^{2}, \text { if } f>u \\
0, \text { if } f=u \\
\left(f u-u^{2}\right) /(\text { total })^{2}, \text { if } u>f
\end{array}\right.
$$


where $f=$ the number of favourable recording units for an agency in a given time period; $u=$ the number of unfavourable recording units for the agency in that time period; and total $=$ the total number of recording units for the agency in that time period. The range of this variable is -1 to 1 , where 1 indicates all favourable coverage, -1 indicates all unfavourable coverage, and 0 indicates a balance between the two over the time period.

\section{Empirical analysis}

The dataset encompasses all editorial articles, comments, and interviews in the daily broadsheet newspapers on the national competition commissions, during the years 2006-2007. The selected newspapers represent the so-called quality press, as usually defined in Switzerland and the United Kingdom.

\section{Data}

- Case 1: United Kingdom (325 articles): The Daily; Telegraph (63 articles), The Financial Times (70 articles), The Guardian (62 articles), The Independent (64 articles), The Times (66 articles).

- Case 2: Switzerland (214 articles): 24 Heures (11 articles), Basler Zeitung (28 articles), Der Bund (23 articles), Neue Zuercher Zeitung (54 articles), Tages Anzeiger (55 articles), Le Temps (31 articles), Tribune de Genève (12 articles).

Before the analysis, the consistency of the coding procedure was examined through the recoding of a random sample of articles by another researcher to establish intercoder reliability with Krippendorff's Alpha (Krippendorff, 2004), using the SPSS macro developed by Hayes (Hayes and Krippendorff, 2007). The result was a satisfactory level of intercoder reliability that was representative of the population at $95 \%$ : K-ALPHA $=0.7194 .{ }^{8}$ Then, a principal component analysis (PCA) was used to explore the structure of the dataset and to examine whether the aforementioned four criteria were adequate for measuring credibility and efficiency. ${ }^{9}$ It appears that the selected criteria, although fundamentally unrelated, as expected, tend to cluster into groups that correspond approximately to the dimensions of credibility and efficiency as identified previously.

\footnotetext{
${ }^{8} \mathrm{~K}$-Alpha follows a quite demanding test of reliability, because data coding is considered reliable not simply when the null hypothesis that agreement occurs by chance can be rejected with statistical confidence, but when it is known for a fact that data will not deviate too much from perfect agreement. According to Krippendorff (2004), there is no set answer to what constitutes a good level of reliability. A level of 0.7 means that at least $70 \%$ of the data are perfectly coded to a degree better than chance. This level is probably not 'beyond reasonable doubt' when the life of someone is directly affected, such as in court proceedings or in some medical tests. But it can be considered good for most types of content analyses, especially for social science research.

9 The principal component loadings are as follows: CRED2 $=0.987$; CRED1 $=0.839$; CRED4 $=$ 0.843 ; EFFIC2 $=0.731$; EFFIC4 $=0.655$; CRED3 =0.624; EFFIC1 $=0.620$; EFFIC2 $=0.566$.
} 


\section{Results}

The empirical analysis focused on six issues, in accordance with the theoretical expectations outlined above, which correspond to the minimal prerequisites to consider the media as a potential accountability forum for IRAs. The first three items illustrate to what extent the media give an account of agencies' regulatory actions; the other three indicate the positive or the negative tone of media coverage as a form of symbolic reward or sanction. The systematic study of a 'most likely' and a 'least likely' case as regards news coverage - the British and Swiss competition commissions - allows enhanced analytical leverage in the comparison and explores the cross-case validity of prospects regarding agencies' media accountability.

1) Frequency in comparison with other issues. Calculations based on data from Pfetsch et al., allow the illustration of the annual average number of editorial comments per newspaper regarding seven relevant policy issues: monetary politics, agriculture, immigration, troop deployment, retirement/pensions, education, and European integration; that is, 12.04 for the United Kingdom and 7.25 for Switzerland (Pfetsch et al., 2004). In comparison, the average annual coverage of the UK competition commission corresponds to 21.70 editorial comments per newspaper, and, respectively, to 13.00 related to the Swiss competition commission. These averages represent levels comparable to those of the most salient policy issues, such as European integration.

2) Trend. There was an overall increase in the frequency of articles evaluating the two competition commissions under investigation: from 137 news items in 2006 to 188 in 2007 on the UK CC, and from 70 to 142 on the Swiss ComCo (Figure 1). More precisely, the average quarterly growth of news coverage was $12.28 \%$ in the United Kingdom and $20.36 \%$ in Switzerland during the time period investigated. This trend is remarkable in comparison with the activity of the media on the seven salient policy issues studied by Pfetsch et al., which remained fairly constant over time (Pfetsch et al., 2004). When the type of article is considered, it appears that,
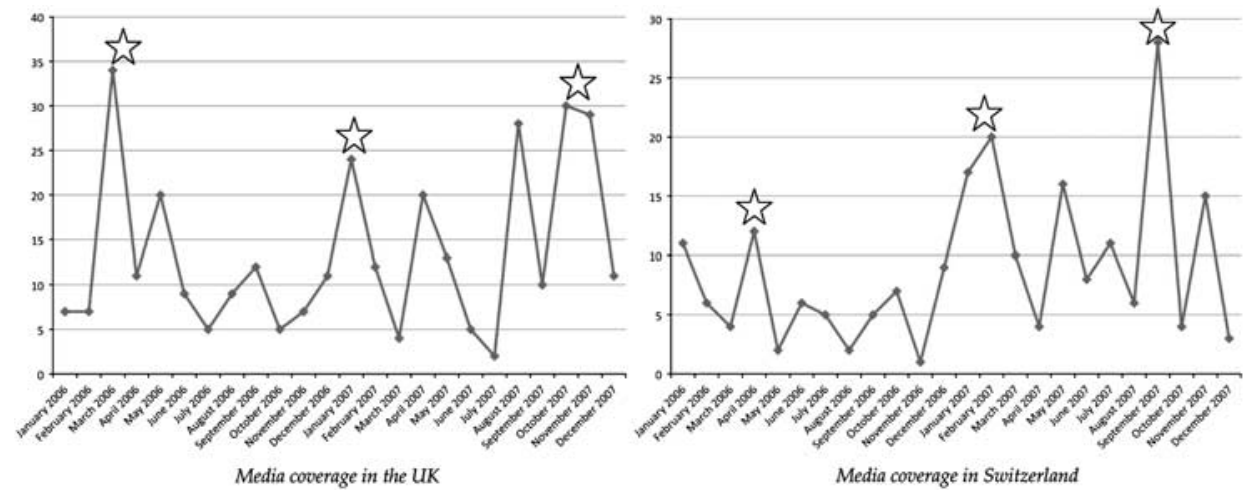

Figure 1 Media coverage of the British Competition Commission and the Swiss Competition Commission. 
Table 1. Media favourableness

\begin{tabular}{lcccc}
\hline \hline & Credibility CC & Efficiency CC & Credibility ComCo & Efficiency ComCo \\
\hline 1 & 20 & 65 & 2 & 45 \\
0 & 300 & 135 & 195 & 89 \\
-1 & 5 & 125 & 20 & 80 \\
$c$ & 0.48 & -0.19 & -0.74 & -0.18 \\
\hline \hline
\end{tabular}

$\mathrm{CC}=$ British Competition Commission; $\mathrm{ComCo}=$ Swiss Competition Commission

on average, from 2006 to 2007, the increase is $71 \%$ for comments, $78 \%$ for editorials, and $32 \%$ for interviews.

3) Regulatory cycle. The trend in news coverage roughly follows the agencies' regulatory agenda, as it tended to cluster in relation to specific regulatory issues by peaking significantly around important events, such as the beginning of an investigation, a crucial decision, or the publication of the annual report. As indicated by the white stars in Figure 1, 13 articles were published in the United Kingdom when a full competition inquiry into the dominance of large British grocers was announced (10 March 2006). The publication of another 15 articles corresponded to the unveiling of the initial findings of the CC's investigation on the grocery market (24 January 2007). Eighteen articles included a sensible CC report on the large supermarkets' dominance (1 November 2007). In Switzerland, meanwhile, 5 articles were published after ComCo's decision to sanction the country's leading telecommunications company for abusing its dominant position (11 April 2006). A total of nine articles were published before the disclosure of the initial position of the Swiss ComCo on an exceptional merger in the grocery market (17 February 2007). In addition, 13 articles reported and discussed the decision made by ComCo relative to that issue (5 September 2007). At the same time, the average tone was not decisively contingent upon specific events, but positive or negative evaluations of regulatory actions by the investigated competition agencies followed comparable patterns across issues (when also controlling for newspaper type).

4) Media bias for credibility. The last row of Table 1 presents the coefficients of media favourableness. ${ }^{10}$ According to media coverage, credibility was considered significantly more positive for the British CC (a coefficient of media favourableness of 0.48 or a differential between positive and negative cases of +5 percentage points) than for the Swiss ComCo (a coefficient of -0.74 or a differential of $-8 \%)$. As regards credibility, coefficients of media favourableness display absolute values that are distant from zero, indicating that media evaluations of agencies are consistent over news articles. In addition, Table 1 shows a good deal of 'neutral' articles, which is as expected according to the coding procedure.

5) Media bias for efficiency. The tone of the evaluations of the agencies' efficiency was almost identical in the United Kingdom and in Switzerland. In both cases,

${ }^{10}$ Excluding the 0 in order to improve the interpretation of results. 


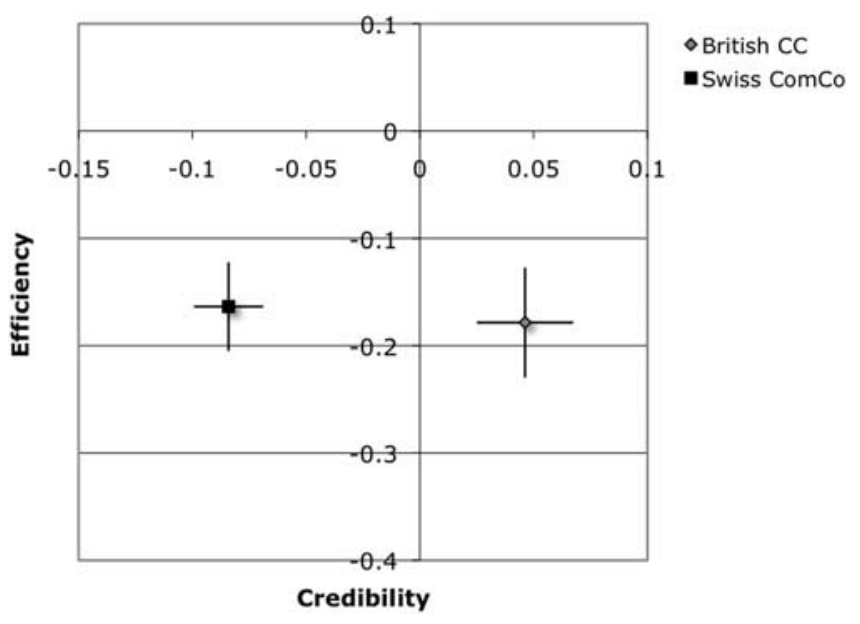

Figure 2 The tone of the media coverage of the British Competition Commission and the Swiss Competition Commission.

there were more negative articles than positive ones. The coefficient of media favourableness was -0.19 in the United Kingdom $(-19 \%)$ and $-0.18(-16 \%)$ in Switzerland; therefore, the CC was evaluated slightly more negatively than the ComCo on this dimension (but both coefficients are quite close to zero). Figure 2 displays a scatterplot showing where the two IRAs are situated according to the mean values of their media evaluations of credibility and efficiency (the small bars represent the standard errors). ${ }^{11}$ This scatterplot allows a comprehensive comparison of media evaluations of the two agencies. As regards efficiency, the tone of media coverage is similar in both cases, and constantly negative; instead, credibility is positively evaluated for the British agency but negatively evaluated in the Swiss case.

6) Content. The element that received the most intensive media coverage by far was 'efficiency' in both cases. Among all articles referring to credibility or efficiency, $88 \%$ evaluated the efficiency of the British CC and $85 \%$ evaluated the efficiency of the Swiss ComCo, respectively. Figure 3 illustrates the relevance of each criterion of the coding for the aggregated evaluation of credibility and efficiency, respectively. Concerning the British CC, the analysis shows that the positive evaluation of credibility is predominantly because it is perceived as being largely separated from politicians and organized interests. On the other hand, its negative reputation for efficiency stems largely from a harmful evaluation of cost-benefit gains. Pertaining to the Swiss ComCo, it appears that

\footnotetext{
11 The mean values and 95\% confidence intervals of the differences are as follows: Credibility of the British CC: $M=0.0462$; CI $=0.0163-0.0760$. Efficiency of the British CC: $M=-0.1785 ; \mathrm{CI}=-0.2597$ to -0.0972 . Credibility of the Swiss ComCo: $M=-0.0841$; CI $=-0.1259$ to -0.0423 . Efficiency of the Swiss ComCo: $M=-0.1636$; CI $=-0.2644$ to -0.0627 .
} 


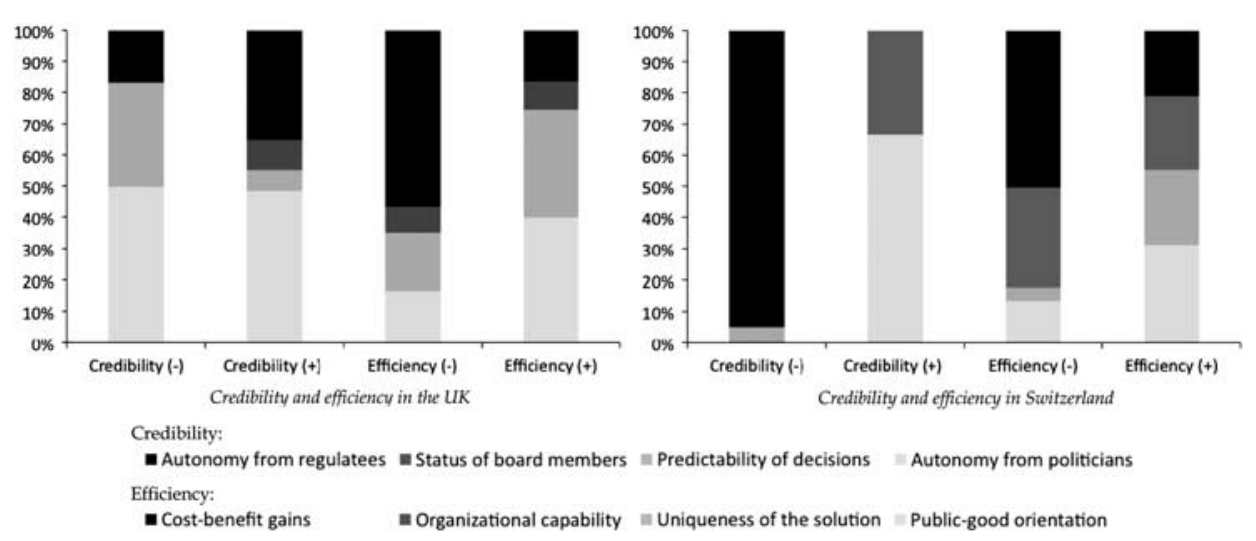

Figure 3 The criteria for credibility and efficiency of the British Competition Commission and the Swiss Competition Commission.

the negative evaluation of credibility is almost entirely because it is perceived as having scarce autonomy from those being regulated, whereas its perceived poor efficiency derives principally from a negative evaluation of organizational capabilities (i.e. human and financial resources) and from the perception of low cost-benefit gains.

\section{Discussion}

The expectation that the media can function as an 'accountability forum' (Bovens, 2007) for IRAs finds support in the cases of the British CC and the Swiss ComCo. To begin with, these agencies seem to be consistently scrutinized by the media, which give account of their regulatory activities quite regularly. (1) The coverage of the agencies in terms of the average annual number of editorial comments per newspaper is well above the average in both countries, in comparison with other relevant policy issues and (2) such coverage tends to increase over time. More importantly, (3) media coverage appears roughly in line with the regulatory cycle, with news peaks around crucial events for the IRAs under examination: the opening of new inquiries, the publication of the results of previous investigations, and key decisions such as important sanctions on regulated industries.

Pertaining to the application of symbolic rewards and sanctions, the results are also mostly in line with expectations. First, (4) a systematic positive bias for credibility can be dismissed, given that the British CC benefits from an excellent media evaluation of credibility, whereas the Swiss ComCo has a negative media evaluation of credibility. Similarly, (5) the existence of a negative bias as regards efficiency is improbable because, although persistently negative, the coefficients of media favourableness are quite close to zero, indicating a good balance between 
negative and positive evaluations. However, the fact that the average tone for efficiency is clearly negative, even for the 'most likely' case of the CC, where one would expect a greater number of positive evaluations, is quite surprising and deserves further investigation. Finally, (6) the content of media coverage is largely in harmony with those topics that can be considered of general interest to the public: namely, the 'autonomy' of agencies as regards credibility and their 'cost-benefit gains' as regards efficiency.

These results are not only relevant for the literature on regulatory governance but also indicate the analytical relevance of the concept of 'mediatization' (Mazzoleni and Schulz, 1999; Kepplinger, 2002; Strömbäck and Esser, 2009), according to which the media are becoming social institutions that operate according to their own logic and have an autonomous impact on political actors and political phenomena (Mazzoleni and Schulz, 1999; Kepplinger, 2002; Strömbäck and Esser, 2009). Following this perspective, it seems that the growing importance of IRAs is recognized by the news media, which report IRAs' activity and mediate their communication, with increasing frequency and evaluating them according to the 'official goals' of delegation, in terms of credibility and efficiency, eventually making ordinary citizens potentially more aware of what IRAs do. Before concluding, it is fair to note that these findings are expected to account for cases presenting similar characteristics, that is, powerful, independent, mediatized regulators in Western Europe, and that they hold within the context of the quite limited research goal of this article, that is, the exploration of the role that media can play as a necessary but insufficient component in a 'multi-pronged' accountability system for independent regulatory agencies (Majone, 2002).

\section{Conclusion}

The purpose of this article was to assess whether the media can function as an 'accountability forum' (Bovens, 2007) for IRAs. With this aim, it explored the media's coverage of IRAs according to the official rationales that justified decisions to delegate public authority from governments to this type of nonmajoritarian institutions: the enhancement of regulatory credibility and the improvement of decision-making efficiency. This approach is relevant not only because public communication is a requisite for the responsiveness of political institutions towards citizens but also because the media represent a venue for policy-makers for the appraisal of regulatory outcomes. The two components of accountability - to give an account and to reward and sanction - are examined through the comparison of a 'most likely' and a 'least likely' case among Western European regulators (i.e. the British CC and the Swiss ComCo, respectively). During the period investigated (2006-2007), media attention pertaining to the regulation of competition in both countries was primarily directed towards market concentration in the grocery sector. This quite exceptional situation allowed the endogenizing of the possible effects of issue-specific conditions. 
The main results can be summarized as follows: IRAs seem accountable to the media, given that the average annual coverage of the Swiss and UK competition commissions corresponds to the level of the most salient policy issues, and, in addition, follows a positive trend. Moreover, media attention is approximately in line with the regulatory cycle of agencies. Concerning symbolic rewards and sanctions by the media, the findings corroborate expectations concerning the tone of editorial comments. Evidence indeed confirms the absence of a systematic positive bias on credibility or a negative bias on efficiency when evaluating IRAs. Nevertheless, the case of the CC shows that even well-endowed IRAs do not necessarily benefit from a positive media evaluation on efficiency. It is impossible at this stage to say whether this result stems from a misrepresentation of this particular dimension or whether it is connected to substantial underperformances by those IRAs under scrutiny. However, if supported by further research, these results might defy the popular ambition of designing a structure of delegation that simultaneously enhances regulatory credibility through independence and decision-making efficiency through the simultaneous application of 'ex-ante', 'expost', or 'ongoing' control mechanisms. Furthermore, in line with other research studies, this article confirms that IRAs can be formally independent and yet be considered under control (Laegreid et al., 2008), with the application of the appropriate 'ex-post' accountability mechanisms (Busuioc, 2009).

These exploratory findings are relevant not only for the burgeoning literature on the spread of regulatory capitalism and the functioning of IRAs (Levi-Faur, 2006a, b; Gilardi, 2008) but also for the discussion regarding the accountability of regulatory governance and the role of media in regulatory policy-making, especially regarding the so-called democratic deficit of the regulatory state. This article offers both good and bad news to the proponents of media scrutiny as an alternative procedure for making independent regulators accountable and perhaps enhancing their legitimacy, following the inappropriateness of traditional forms of upward and downward accountability for institutions that lack input legitimacy by design (Majone, 1994a; Scott, 2000; Lodge, 2004; Maggetti, 2009a; Maggetti, 2010). On the one hand, the media can possibly act as a proper accountability forum that provides the public with consistent evaluations of agencies' work. On the other, whereas a positive media evaluation of credibility has proven attainable under specific conditions, the corresponding evaluation of efficiency seems chimerical for IRAs, even in the 'most likely' case, potentially compromising the reputation of (some) independent regulators in the eyes of ordinary citizens.

\section{Acknowledgements}

Helpful comments have been received from Dietmar Braun, Fabrizio Gilardi, Yannis Papadopoulos, Claudio M. Radaelli, and three anonymous referees. This research is part of the NCCR Democracy (http://www.nccr-democracy.uzh.ch/) and is funded by the Swiss National Science Foundation. 


\section{References}

Altheide, D.L. and R.P. Snow (1988), 'Toward a theory of mediation', Communication Yearbook 11: 194-223.

Armingeon, K. (2002), 'The effects of negotiation democracy: a comparative analysis', European Journal of Political Research 41: 81-105.

Arnold, R.D. (2004), Congress, the Press, and Political Accountability. Princeton: Princeton University Press.

Balboni, B. (2008), 'Perceived corporate credibility as the emergent property of corporate reputation's transmission process'. MPRA Paper, pp. 1-9.

Barro, R. and D. Gordon (1983), 'Rules, discretion and reputation in a model of monetary policy', Journal of Monetary Economics 12: 101-121.

Bendor, J., A. Glazer and T. Hammond (2001), 'Theories of delegation', Annual Review of Political Science 4: 235-269.

Besley, T. and R. Burgess (2001), 'Political agency, government responsiveness and the role of the media', European Economic Review 45: 629-640.

Besley, T. and A. Prat (2006), 'Handcuffs for the grabbing hand? Media capture and government accountability', The American Economic Review 96: 720-736.

Besley, T., R. Burgess and A. Prat (2002), 'Mass media and political accountability', in The World Bank (ed.), The Right to Tell: the Role of Mass Media in Economic Development, Washington: WBI, pp. 45-60.

Blinder, A.S. (1999), 'Central bank credibility: why do we care? How do we build it?', The American Economic Review 90: 1421-1431.

Blühdorn, I. (2006), 'Democracy, efficiency, futurity: contested objectives of societal modernization', in I. Bluehdorn and U. Jun (eds), Economic Efficiency - Democratic Renewal. Contested Modernization in Britain and Germany, Lanham, MD, USA: Lexington Press, pp. 69-98.

Bovens, M. (2007), 'Analysing and assessing accountability: a conceptual framework', European Law Journal 13: 447-468.

Brabazon, T. (2000), 'Behavioural finance: a new sunrise or a false dawn?', in CoIL Summer School 2000, University of Limerick: Department of Accountancy, University College Dublin pp. 1-8.

Braun, D. (2003), 'Dezentraler Und Unitarischer Foderalismus. Die Schweiz Und Deutschland Im Vergleich', Swiss Political Science Review 9: 57-90.

Braun, D. and F. Gilardi (2006), Delegation in Contemporary Democracies, Abingdon, Oxon; New York: Routledge.

Brunetti, A., G. Kisunko and B. Weder (1998), 'Credibility of rules and economic growth: evidence from a worldwide survey of the private sector', The World Bank Economic Review 12: 353-384.

Bryant, J. and D. Zillmann (2002), Media Effects: Advances in Theory and Research, Mahwah, NJ: L. Erlbaum.

Busuioc, M. (2009), 'Accountability, control and independence: the case of European agencies', European Law Journal 15: 599-615.

Carpenter, D.P. (2001a), 'State building through reputation building: coalitions of esteem and program innovation in the national postal system, 1883-1913', Studies in American Political Development 14: 121-155.

- (2001b), The Forging of Bureaucratic Autonomy: Reputations, Networks, and Policy Innovation in Executive Agencies, 1862-1928, Princeton, NJ: Princeton University Press.

- (2002), 'Groups, the media, agency waiting costs, and FDA drug approval', American Journal of Political Science 46: 490-505.

Castiglione, D. (2006), 'Accountability', in M. Bevir (ed.), Encyclopedia of Governance, London: Sage, pp. $1-7$.

Christensen, T. and P. Laegreid (2003), 'Administrative reform policy: the challenges of turning symbols into practice', Public Organization Review 3: 3-27.

- (2006a), 'Agencification and regulatory reforms', in T. Christensen and P. Laegreid (eds), Autonomy and Regulation: Coping with Agencies in the Modern State, Cheltenham: Edward Elgar, pp. 8-52. 
- (2006b), 'Autonomy and Regulation: Coping with Agencies in the Modern State', Cheltenham: Edward Elgar.

- (2007), 'Regulatory agencies - the challenges of balancing agency autonomy and political control', Governance 20: 499-520.

Christensen, J.G. and K. Yesilkagit (2006), 'Political responsiveness and credibility in regulatory administration', in T. Christensen and P. Laegreid (eds), Autonomy and Regulation: Coping with Agencies in the Modern State, Cheltenham: Edward Elgar, pp. 203-234.

Clark, M. (2005), 'Scandalous! The electoral effects of valence issues in Western Europe, 1976-1998', Annual meeting of the Midwest Political Science Association, Chicago, pp. 1-41.

Coen, D. and A. Heritier (2005), Refining Regulatory Regimes: Utilities in Europe, Cheltenham: Edward Elgar.

Coglianese, C. and M. Howard (1998), 'Getting the message out: regulatory policy and the press', Politics 3: 39-55.

Cook, T.E. (1998), Governing with the News: the News Media as a Political Institution. Chicago: University of Chicago Press.

Curran, J. (2005), 'What democracy requires of the media', in G. Overholser and K.H. Jamieson (eds), The Press, USA: Oxford University Press, pp. 120-140.

Dahl, R.A. (1989), Democracy and its Critics, New Haven: Yale University Press.

de Jonge, J., H. van Trijp, R. Jan Renes and L. Frewer (2007), 'Understanding consumer confidence in the safety of food: its two-dimensional structure and determinants', An International Journal 27: 729-740.

de Vreese, C.H., S.A. Banducci, H.A. Semetko and H.G. Boomgaarden (2006), 'The news coverage of the 2004 European parliamentary election campaign in 25 countries', European Union Politics 7: 477-504.

Deephouse, D.L. (2000), 'Media reputation as a strategic resource: an integration of mass communication and resource-based theories', Journal of Management 26: 1091-1112.

Doyle, G. (2002), Media Ownership: the Economics and Politics of Convergence and Concentration in the UK and European Media, Thousand Oaks: Sage.

Drazen, A. and P. Masson (1994), 'Credibility of policies versus credibility of policymakers', Quarterly Journal of Economics 109: 735-754.

Dunleavy, P. and H. Margetts (2001), 'From majoritarian to pluralist democracy?: electoral reform in Britain since 1997', Journal of Theoretical Politics 13: 295-319.

Eilders, C. (2000), 'Media as political actors? Issue focusing and selective emphasis in the German quality press', German Politics 9: 181-206.

- (2002), 'Conflict and consonance in media opinion: political positions of five German quality newspapers', European Journal of Communication 17: 25-63.

Elgie, R. and I. McMenamin (2005), 'Credible commitment, political uncertainty or policy complexity? Explaining variations in the independence of non-majoritarian institutions in France', British Journal of Political Science 35: 531-548.

Emery, Y. and D. Giauque (2004), Paradoxes de la gestion publique. Paris: L'Harmattan.

Epstein, D. and S. O'Halloran (1999), Delegating Powers: a Transaction Cost Politics Approach to Policy Making Under Separate Powers, Cambridge, UK; New York: Cambridge University Press.

Follesdal, A. and S. Hix (2006), 'Why there is a democratic deficit in the EU: a response to Majone and Moravcsik', Journal of Common Market Studies 44: 533-562.

Fox, J. (2000), Civil Society and Political Accountability: Propositions for Discussion, USA: University of Notre Dame.

Franchino, F. (2002), 'Efficiency or credibility? Testing the two logics of delegation to the European Commission', Journal of European Public Policy 9: 677-694.

GCR (2006), 'The 2006 handbook of competition enforcement agencies', Global Competition Review Special Report, December, pp. 1-60.

Gentzkow, M. and J.M. Shapiro (2006), 'Media bias and reputation', Journal of Political Economy 114: 280-316.

Gerber, E.R. (1999), The Populist Paradox: Interest Group Influence and the Promise of Direct Legislation. Princeton: Princeton University Press. 
Gerring, J. (2004), 'What is a case study and what is it good for?', American Political Science Review 98: $341-354$.

- (2007a), 'Is there a (viable) crucial-case method?', Comparative Political Studies 40: 231-253.

- (2007b), Case Study Research: Principles and Practices, Cambridge: Cambridge University Press.

Gilardi, F. (2002), 'Policy credibility and delegation to independent regulatory agencies: a comparative empirical analysis', Journal of European Public Policy 9: 873-893.

- (2005), 'The institutional foundations of regulatory capitalism: the diffusion of independent regulatory agencies in Western Europe', The ANNALS of the American Academy of Political and Social Science 598: 84-101.

- (2008), Delegation in the Regulatory State: Independent Regulatory Agencies in Western Europe, Northampton, MA: Edward Elgar.

Goertz, G. (2006), Social Science Concepts: a User's Guide, Princeton: Princeton University Press.

Hall, P.A. and D.W. Soskice (2001), Varieties of Capitalism: the Institutional Foundations of Comparative Advantage, Oxford, England, New York: Oxford University Press.

Hallin, D.C. and P. Mancini (2004), Comparing Media Systems: Three Models of Media and Politics. Cambridge: Cambridge University Press.

Hayes, A.F. and K. Krippendorff (2007), 'Answering the call for a standard reliability measure for coding data', Communication Methods and Measures 1: 77-89.

Héritier, A. and S. Eckert (2008), 'New modes of governance in the shadow of hierarchy: self-regulation by industry in Europe', Journal of Public Policy 28: 113-138.

Hodge, G.A. and K. Coghill (2007), 'Accountability in the privatized state', Governance 20: 675-702.

Hood, C., H. Rothstein and R. Baldwin (2001), The Government of Risk: Understanding Risk Regulation Regimes, Oxford: Oxford University Press.

Hopenhayn, H. and S. Lohmann (1996), 'Fire-alarm signals and the political oversight of regulatory agencies', Journal of Law, Economics, and Organization 12: 196-213.

Katzenstein, P.J. (2003), 'Small states and small states revisited', New Political Economy 8: 9-30.

Kepplinger, H.M. (2002), 'Mediatization of politics: theory and data', Journal of Communication 52: 972-986.

Kepplinger, H.M. and H. Weißbecker (1991), 'Negativität als Nachrichtenideologie', Publizistik 36: 330-342.

Kepplinger, H.M., W. Donsbach, H.B. Brosius and J.F. Staab (2004), 'Media tone and public opinion: a longitudinal study of media coverage and public opinion on Chancellor Kohl', International Journal of Public Opinion Research 1: 326-342.

Kim, J.N., S.B. Bach and I.J. Clelland (2007), 'Symbolic or behavioral management? Corporate reputation in high-emission industries', Corporate Reputation Review 10: 77-98.

Knill, C. (1998), 'European policies: the impact of national administrative traditions', Journal of Public Policy 18: 1-28.

Krause, G.A. and J.W. Douglas (2005), 'Institutional design versus reputational effects on bureaucratic performance: evidence from US government macroeconomic and fiscal projections', Journal of Public Administration Research and Theory 15: 281-306.

Krippendorff, K. (2004), Content Analysis: an Introduction to its Methodology, Thousand Oaks, CA: Sage.

Kydland, F. and E. Prescott (1977), 'Rules rather than discretion: the inconsistency on optimal plans', Journal of Political Economy 85: 473-491.

Laegreid, P., P.G. Roness and K. Rubecksen (2008), 'Controlling regulatory agencies', Scandinavian Political Studies 31: 1-26.

Lang, G.E. and K. Lang (1984), Politics and Television Re-viewed, Beverly Hills, CA: Sage Publications.

Lee, M. (1999), 'Reporters and bureaucrats: public relations counter-strategies by public administrators in an era of media disinterest in government', Public Relations Review 25: 451-463.

Levi-Faur, D. (2005), 'The global diffusion of regulatory capitalism', Annals, AAPSS 598: 12-32.

(2006a), 'Regulatory capitalism: the dynamics of change beyond telecoms and electricity', Governance 19: 497-525.

- (2006b), 'Varieties of regulatory capitalism: sectors and nations in the making of a new global order', Governance 19: 363-366. 
Lodge, M. (2002), 'The wrong type of regulation? Regulatory failure and the railways in Britain and Germany', Journal of Public Policy 22: 271-297.

- (2004), 'Accountability and transparency in regulation: critiques, doctrines and instruments', in J. Jordana and D. Levi-Faur (eds), The Politics of Regulation, Cheltenham: Edward Elgar, pp. 124-144.

Louw, P.E. (2005), The Media and Political Process. Sage Publications Ltd, pp. 311.

Maeda, Y. and M. Miyahara (2003), 'Determinants of trust in industry, government, and citizen's groups in Japan', Corporate Reputation Review 10: 303-310.

Maggetti, M. (2007), 'De facto independence after delegation: a fuzzy-set analysis', Regulation \& Governance 1: 271-294.

- (2009a), 'Delegated authority: legitimizing independent regulatory agencies', in I. Blühdorn (ed.), In Search of Legitimacy. Policy Making in Europe and the Challenge of Societal Complexity, Opladen/Farmington Hills, MI: Barbara Budrich.

- (2009b), 'The role of independent regulatory agencies in policy-making: a comparative analysis', Journal of European Public Policy 16: 445-465.

- (2010), 'Legitimacy and accountability of independent regulatory agencies: a critical review', Living Reviews in Democracy 2: 1-9.

Maggetti, M. and F. Gilardi (2010), 'Establishing regulatory networks and the diffusion of best practices', Network Industries Quarterly 12: 10-13.

Maggetti, M., A. Afonso and M.C. Fontana (2011), 'The more it changes, the more it stays the same?', in C. Trampusch and A. Mach (eds), Switzerland in Europe, Oxon: Routledge, pp. 205.

Majone, G. (1994a), Independence vs. Accountability?: Non-Majoritarian Institutions and Democratic Government in Europe. Florence: European University Institute.

— (1994b), 'The rise of the regulatory state in Europe', West European Politics 17: 77-101.

Majone, G. (1996a), "Temporal Consistency and Policy Credibility: Why Democracies Need Nonmajoritarian Institutions.” EUI Working Paper SPS 96, Florence: European University Institute, pp. $1-31$.

Majone, G. (1996b), Regulating Europe, London, New York: Routledge.

- (1997a), The Agency Model: The Growth of Regulation and Regulatory Institutions in the European Union. Florence: European University Institute.

- (1997b), 'From the positive to the regulatory state: causes and consequences of changes in the mode of governance', Journal of Public Policy 17: 139-167.

- (1999), 'The regulatory state and its legitimacy problems', West European Politics 22: 1-24.

- (2000), 'The credibility crisis of community regulation', Journal of Common Market Studies 38: 273-302.

- (2001a), 'Regulatory legitimacy in the United States and the European Union', in K. Nicolaidis and R. Howse (eds), The Federal Vision. Legitimacy and Levels of Governance in the United States and the European Union, Oxford: Oxford University Press, pp. 252-275.

- (2001c), 'Two logics of delegation: agency and fiduciary relations in EU governance', European Union Politics 2: 103-122.

- (2002), 'Europe's "democratic deficit”: the question of standards', European Law Journal 4: 5-28.

- (2005), 'Delegation of powers and the fiduciary principle', CONNEX Workshop, Paris.

Manin, B. (1996), Principes du gouvernement représentatif, Paris: Flammarion.

Mazzoleni, G. (1987), 'Media logic and party logic in campaign coverage: the Italian general election of 1983', European Journal of Communication 2: 81-103.

Mazzoleni, G. and W. Schulz (1999), “ “ Mediatization” of politics: a challenge for democracy?’, Political Communication 16: 247-261.

McCubbins, M.D., R.G. Noll and B.R. Weingast (1987), 'Administrative procedures as instruments of political control', Journal of Law, Economics, and Organization 3: 243-277.

Meyer, C. (2004), 'The hard side of soft policy co-ordination in EMU: the impact of peer pressure on publicized opinion in the cases of Germany and Ireland', Journal of European Public Policy 11: 814-831.

Moran, M. (2002), 'Review article: understanding the regulatory state', British Journal of Political Science 32: 391-413. 
- (2003), The British Regulatory State: High Modernism and Hyper-innovation, Oxford; New York: Oxford University Press.

Mulgan, R. (2000), “"Accountability”: an ever-expanding concept?', Public Administration 78: 555-573.

- (2003), Holding power to account: accountability in modern democracies. Houndmills, Basingstoke, Hampshire, New York: Palgrave Macmillan.

Norris, P. (2001), 'The twilight of Westminster? Electoral reform and its consequences', Political Studies 49: 877-900.

O’Donnell, G.A. (1998), 'Horizontal accountability in new democracies', Journal of Democracy 9: 112-126.

OECD (2005), 'Switzerland - the role of competition policy in regulatory reform', OECD Reviews of Regulatory Reform.

Papadopoulos, Y. (2008), 'Europeanization? Two logics of change of policy-making patterns in Switzerland', Journal of Comparative Policy Analysis 10: 255-278.

Peters, B.G. (2004), '2. Administrative traditions and the Anglo-American democracies', in J. Halligan (ed.), Civil Service Systems in Anglo-American Countries, Cheltenham: Edward Elgar.

Peters, R.G., V.T. Covello and D.B. McCallum (1997), 'The determinants of trust and credibility in environmental risk communication: an empirical study', Risk Analysis 17: 43-54.

Pfetsch, B., S. Adam, B. Berkel and J.D. Medrano (2004), The Voice of the Media in European Public Sphere: Comparative Analysis of Newspaper Editorials, Berlin: Wissenschaftszentrum für Sozialforschung.

Pollack, M.A. (1996), 'The new institutionalism and EC governance: the promise and limits of institutional analysis', Governance 9: 429-458.

Pollitt, C., C. Tablot, J. Caufield and A. Smullen (2004), Agencies: How Governments Do Things Through Semi-Autonomous Organizations, New York: Palgrave Macmillan.

Pollock, T.G. and V.P. Rindova (2003), 'Media legitimation effects in the market for initial public offerings', Academy of Management Journal 46: 631-642.

Radaelli, C.M. and F. De Francesco (2007), Regulatory Quality in Europe: Concepts, Measures and Policy Processes, Manchester: Manchester University Press.

Roberts, A. (2001), 'Structural pluralism and the right to information', University of Toronto Law Journal 51: 243-271.

Roberts, N.C. (2002), 'Keeping public officials accountable through dialogue: resolving the accountability paradox', Public Administration Review 62: 658-669.

Sarcinelli, U. (1987), Symbolische Politik: zur Bedeutung symbolischen Handelns in der Wablkampfkommunikation der Bundesrepublik Deutschland, Opladen: Westdeutscher Verlag.

Schedler, A. (1999), 'Conceptualizing accountability', in A. Schedler, L. Diamond, and M.F. Plattner (eds), The Self-restraining State: Power and Accountability in New Democracies. Boulder, Colorado: Lynne Rienner Publishers, pp. 13-28.

Scott, C. (2000), 'Accountability in the regulatory state', Journal of Law and Society 27: 38-60.

Seawright, J. and J. Gerring (2008), 'Case selection techniques in case study research: a menu of qualitative and quantitative options', Political Research Quarterly 61: 294-308.

Shepsle, K.A. (1991), 'Discretion, institutions, and the problem of government commitment', in P. Bourdieu and J. Coleman (eds), Social Theory for a Changing Society, Boulder; New York: Westview Press; Russell Sage Foundation, pp. 245-265.

Snyder, J.M. and D. Strömberg (2008), 'Press coverage and political accountability', Journal of Political Economy 118: 355-408.

Sosay, G. (2006), 'Consequences of legitimizing independent regulatory agencies in contemporary democracies. Theoretical scenarios', in D. Braun and F. Gilardi (eds), Delegation in Contemporary Democracies, Abingdon, Oxon; New York: Routledge, pp. 171-190.

Stimson, J.A., M.B. MacKuen and R.S. Erikson (1994), 'Opinion and policy: a global view', PS: Political Science and Politics 27: 29-34.

Strömbäck, J. and F. Esser (2009), 'Shaping politics: mediatization and media interventionism', in Mediatization. Concept, Changes, Consequences, New York: Peter Lang, S205-S223.

Strömberg, D. (2004), 'Mass media competition, political competition, and public policy', The Review of Economic Studies 71: 265-284. 
Swanson, D.L. (1981), 'A constructivist approach', in D.D. Nimmo and K.R. Sanders (eds), Handbook of Political Communication, Beverly Hills; London: Sage Publication, pp. 169-191.

Swanson, D.L. and P. Mancini (1996), Politics, Media, and Modern Democracy: an International Study of Innovations in Electoral Campaigning and their Consequences. Westport, Conn: Praeger Publishers.

Thatcher, M. (2002a), 'Analysing independent regulatory agencies in Western Europe: functional pressures mediated by context', Swiss Political Science Review 8: 103-110.

— (2002b), 'Analysing regulatory reform in Europe', Journal of European Public Policy 9: 859-872.

- (2002c), 'Delegation to independent regulatory agencies: pressures, functions and contextual mediation', West European Politics 25: 125-147.

- (2002d), 'Regulation after delegation: independent regulatory agencies in Europe', Journal of European Public Policy 9: 954-972.

Thatcher, M. and A. Stone Sweet (2002), 'Theory and practice of delegation to non-majoritarian institutions', West European Politics 25: 1-22.

Varone, F. (2007), 'The federal administration', in U. Klöti, P. Knoepfel, H. Kriesi, W. Linder, Y. Papadopoulos, and P. Sciarini (eds), Handbook of Swiss Politics, Zürich: Neue Zürcher Zeitung Publishing, pp. 282-308.

Verschuere, B., K. Verhoest, F. Meyers and B.G. Peters (2006), '10. Accountability and accountability arrangements in public agencies', in T. Christensen and P. Laegreid (eds), Autonomy and Regulation: Coping with Agencies in the Modern State, Cheltenham: Edward Elgar.

Vibert, F. (2007), The Rise of the Unelected: Democracy and the New Separation of Powers, Cambridge: Cambridge University Press.

Vogel, S.K. (1996), Freer Markets, More Rules: Regulatory Reform in Advanced Industrial Countries, Ithaca, NY: Cornell University Press.

Voltmer, K. (1998), Medienqualität und Demokratie: eine empirische Analyse publizistischer Informations-und Orientierungsleistungen in der Wahlkampfkommunikation, Baden-Baden: Nomos.

- (2010), 'The media, government accountability, and citizen engagement', in P. Norris (ed.), Public Sentinel: News Media and Governance Reform, Washington: World Bank, pp. 395.

Voltmer, K. and C. Eilders (2003), 'The media agenda: the marginalization and domestication of Europe', in K. Dyson and K.H. Goetz (eds), Germany, Europe and the Politics of Constraint, Oxford: Oxford University Press, pp. 173-197.

Walgrave, S., S. Soroka and M. Nuytemans (2008), 'The mass media's political agenda-setting power', Comparative Political Studies 41: 814-836.

Waterman, R.W. and A. Rouse (1999), 'The determinants of the perceptions of political control of the bureaucracy and the venues of influence', Journal of Public Administration Research and Theory 9: 527-569.

Waterman, R.W., A. Rouse and R. Wright (1998), 'The venues of influence: a new theory of political control of the bureaucracy', Journal of Public Administration Research and Theory 8: 13-38.

Widmer, T. and P. Neuenschwander (2004), 'Embedding evaluation in the Swiss federal administration: purpose, institutional design and utilization', Evaluation 10: 388-409.

Wilks, S. (2007), 'Agencies, networks, discourses and the trajectory of European competition enforcement', European Competition Journal 3: 437-464.

Wilks, S. and I. Bartle (2002), 'The unanticipated consequences of creating independent competition agencies', West European Politics 25: 148-172.

Yesilkagit, K. (2004), 'The design of public agencies: overcoming agency costs and commitment problems', Public Administration and Development 24: 119-127.

Zaller, J. (1992), The Nature and Origins of Mass Opinion, Cambridge, New York: Cambridge University Press. 